\title{
Partidos Fracos na Arena Eleitoral e Partidos Fortes na Arena Legislativa: A Conexão Eleitoral no Brasil*
}

Carlos Pereira

Bernardo Mueller

\section{INTRODUÇÃO}

Para a grande maioria dos autores que analisam o sistema político brasileiro, nosso sistema eleitoral e os partidos políticos dele decorrentes funcionam como um verdadeiro obstáculo às iniciativas e preferências do Executivo. Tem sido freqüentemente defendido que o arcabouço institucional do sistema político fornece incentivos desfavoráveis à governabilidade democrática. Desse modo, a principal suposição defendida por esses autores é que o padrão de votação dos membros do Congresso, assim como o nível de fragmentação e indisciplina de seus partidos políticos, estão altamente relacionados às regras pelas quais os legisladores são selecionados pelos cidadãos. Na

\footnotetext{
* Este artigo teve duas motivações. A primeira é a tese de doutorado de Carlos Pereira, defendida em abril de 2000 na New School University, New York, sob a orientação do professor Adam Przeworski. A segunda motivação são as interpretações dos argumentos propostos por Pereira e Mueller no artigo "Comportamento Estratégico em Presidencialismo de Coalizão: As Relações entre Executivo e Legislativo na Elaboração do Orçamento Brasileiro" (Dados, vol. 45, nํ2, 2002, pp. 265-301) desenvolvidas por Argelina Figueiredo e Fernando Limongi no artigo "Incentivos Eleitorais, Partidos e Política Orçamentária", publicado no mesmo número da revista (Dados, vol. 45, no 2, 2002, pp. 303-344). Gostaríamos de agradecer os valiosos comentários de Marcus Melo, Letícia Schwarz, Octavio Amorim Neto e Lúcio Rennó.
}

DADOS - Revista de Ciências Sociais, Rio de Janeiro, Vol. 46, n-1, 2003, pp. 735 a 771. 
realidade, essa vertente analítica considera indisciplina e fragmentação partidária como resultados diretos das regras eleitorais (Ames, 1995a; 1995b; 2001; Mainwaring, 1999; Mainwaring e Shugart, 1997; Mainwaring e Scully, 1995; Haggard, 1995; Haggard e Kaufman, 1992; Lamounier, 1989).

Talvez a origem desse argumento ou a sua interpretação moderna esteja nos trabalhos de Downs (1957) e Mayhew (1974), os quais enfatizam a importância das eleições como fator modulador do comportamento dos políticos, a chamada "conexão eleitoral". Nos termos de Mayhew (idem), "two-arena model", na qual a primeira arena, a eleitoral, condicionaria o comportamento dos políticos na segunda arena, a legislativa. A atuação dos partidos políticos na arena legislativa seria, assim, basicamente, uma conseqüência funcional da necessidade de se vencer eleições. A inferência direta deste argumento, portanto, é que as regras eleitorais incentivam os candidatos a desenvolver relações personalísticas e individuais com suas bases eleitorais, em vez de mediá-las via partidos políticos, e que isso necessariamente acarreta a diminuição do impacto dos partidos políticos na arena legislativa. Ou, como é defendido por Cain et alii (1987), se as ações e serviços orientados para beneficiar as bases eleitorais têm um papel importante na sobrevivência política dos políticos, estes tenderão a focalizar suas ações e decisões políticas essencialmente nos seus redutos eleitorais.

Recentemente, em uma direção oposta, uma série de outros autores (Figueiredo e Limongi, 1995; 1997; 1999; 2000a; 2000b; 2002; Amorim Neto e Santos, 2001; Amorim Neto, 2002; Pereira e Mueller, 2000; Meneguello, 1998) tem questionado esse consenso, baseando-se nos efeitos da centralização decisória no Congresso e nos poderes de legislar do presidente brasileiro. De uma forma geral, esta segunda variante explicativa afirma que o comportamento dos parlamentares no Congresso Nacional não é nada indicativo de fraqueza ou fragmentação do nosso sistema partidário. Tal posição é amparada em evidências de que os parlamentares brasileiros têm se comportado de forma consistentemente coesa e disciplinada de acordo com a indicação dos seus respectivos líderes partidários. Assim, antes de ser um obstáculo, o Congresso brasileiro tem favorecido as iniciativas da Presidência da República, que, em última instância, teria preponderância política e institucional sobre os parlamentares para fazer valer suas preferências. 
Bowler (2000) refere-se a essa abordagem como "one-arena model", uma vez que ela pressupõe serem extremamente fracos os elos entre as arenas eleitoral e legislativa. Precisamente, a abordagem surgiu como resposta às concepções que viam a esfera legislativa formada por indivíduos empreendedores e maximizadores de benefícios eleitorais, destituídos de partidos que restringissem seus comportamentos. Pode-se atribuir aos trabalhos de Gary Cox (1987) e Cox e McCubbins (1993) as tentativas mais elaboradas de "bring the party back in" para explicar o comportamento legislativo não como motivado pelos benefícios decorrentes da "conexão eleitoral", mas sim orientado pelas restrições das regras e procedimentos centralizadores presentes na arena legislativa, que colocam os partidos políticos em vantagem sobre os deputados individualmente. De acordo com esta perspectiva, os partidos políticos resolveriam problemas de ação coletiva dentro do Legislativo tanto ao oferecer uma estrutura institucional para a escolha de políticas como ao garantir comportamentos cooperativos dos deputados. Um dos desdobramentos dessa abordagem partidária (e ao mesmo tempo em forte contraste com a primeira abordagem) é que eventuais alterações ou reformas na arena eleitoral terão pouco ou nenhum impacto no papel dos partidos no Legislativo, principalmente porque os incentivos para se manter partidos coesos e disciplinados estariam concentrados não na arena eleitoral, mas sim na arena legislativa.

Diferentemente das duas abordagens anteriores, o principal argumento deste artigo é o de que o sistema político brasileiro não deve ser caracterizado nem como um sistema puramente descentralizado (como defendido pelos autores da primeira variante explicativa), nem como um sistema puramente centralizado (como defendido pelos autores da segunda variante). Em outras palavras, acreditamos que as duas abordagens discutidas acima oferecem uma explicação parcial e incompleta para o comportamento dos partidos dentro e fora do Legislativo. Defendemos, alternativamente, que o sistema político brasileiro condensa essas duas diferentes e antagônicas forças e incentivos institucionais. De um lado, as regras eleitorais (representação proporcional com lista aberta), o multipartidarismo e o federalismo agem descentralizando o sistema político. De outro lado, as regras internas do processo de decisão dentro do Congresso e os poderes constitucionais do presidente de legislar e de distribuir recursos políticos e financeiros proporcionam grandes incentivos para a cen- 
tralização desse mesmo sistema. Em outras palavras, as regras eleitorais proporcionam incentivos para os políticos se comportarem individualmente, fragilizando, assim, os partidos na arena eleitoral, enquanto as regras internas do Congresso e os poderes presidenciais tornam o comportamento dos parlamentares extremamente dependente da lealdade aos seus respectivos partidos, fortalecendo estes últimos dentro do Congresso.

Na verdade, é o resultado da combinação de ambas as restrições - regras internas no Congresso e poderes do presidente, de um lado, e regras eleitorais, de outro - que definirá os custos relativos do comportamento de voto dos legisladores, bem como de seus partidos políticos. Portanto, a combinação dessas duas forças oferece, simultaneamente, incentivos paradoxais tanto para comportamentos individuais na esfera eleitoral como para comportamentos partidários dentro do Congresso. Resumindo: se, por um lado, pelas regras de seleção dos parlamentares, os deputados recebem incentivos para se comportarem individualmente, por outro lado, em função do funcionamento centralizado do processo decisório interno da Câmara, os deputados recebem incentivos para se comportarem de acordo com o líder do partido e, por que não dizer, de acordo com os interesses do presidente, no caso do presidencialismo de coalizão majoritário brasileiro atual.

Afirmamos, assim, que mesmo um sistema político com incentivos a comportamentos tão conflitantes, como é o brasileiro, proporciona equilíbrio ${ }^{1}$ e estabilidade. Porém, neste caso, o equilíbrio (ausência de caos) do sistema político é extremamente dinâmico, podendo variar de um issue para outro. Precisamente, o equilíbrio dependerá, no fundamental, da capacidade do presidente e dos líderes dos partidos que formam a coalizão de governo no Congresso de utilizarem adequadamente $o$ arsenal de instrumentos institucionais à sua disposição, dentre os quais o de oferecer incentivos - benefícios políticos e financeiros - capazes de proporcionar os melhores retornos eleitorais para os parlamentares. Portanto, a chave para o entendimento da simultaneidade de partidos fracos na arena eleitoral e partidos fortes no espaço congressual e de governo no sistema político brasileiro é a combinação, aparentemente contraditória, de incentivos para o comportamento individual e partidário ao mesmo tempo. Na realidade, o comportamento partidário (não o comportamento individual, como preconiza o "two-arena model") na arena legislativa visa a que os membros desse partido extraiam benefícios individuais controlados pelos 
Quadro 1

Sistema Eleitoral vs. Regras Internas do Congresso

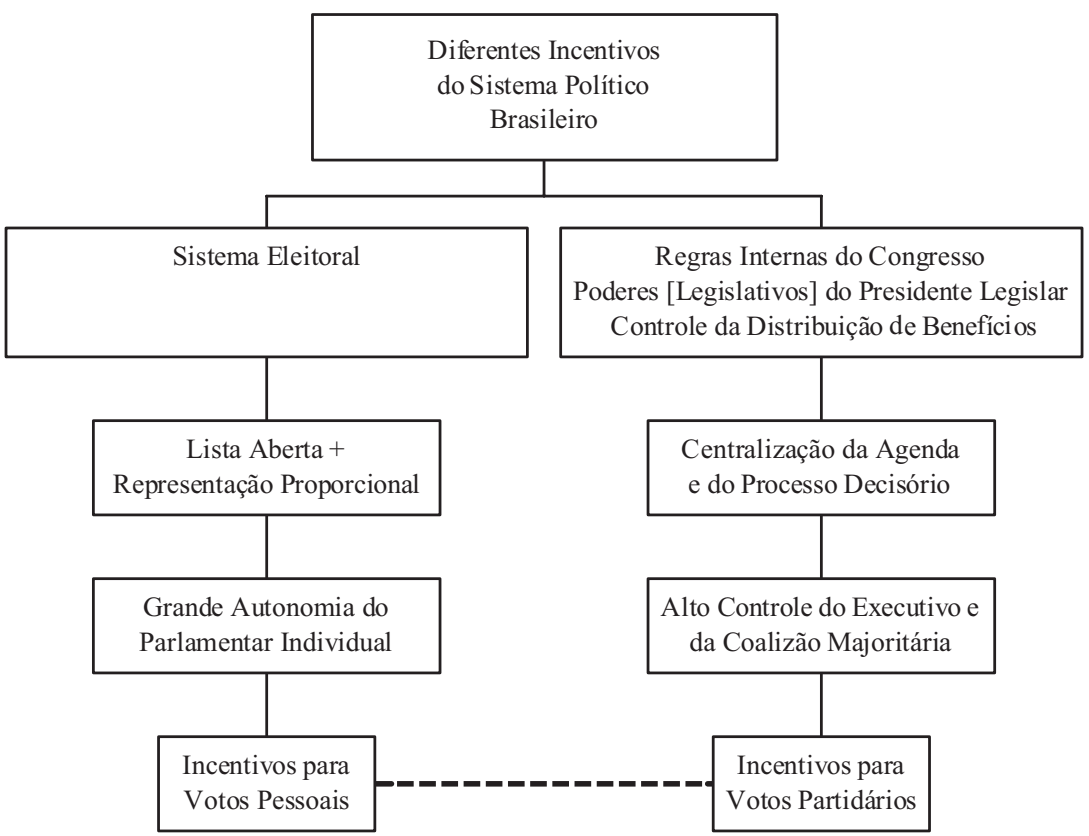

líderes partidários e pelo Executivo a serem utilizados na esfera eleitoral.

Daí os partidos políticos serem tão importantes e fundamentais na arena legislativa brasileira. Principalmente a atuação dos líderes partidários, que concentram poderosas prerrogativas institucionais, tais como nomear e destituir membros e dirigentes das comissões e relatores de projetos; incluir e retirar projetos da pauta do Congresso; determinar se a sua tramitação terá caráter de urgência; orientar o voto de sua bancada no plenário; e, fundamentalmente, negociar junto ao Executivo as demandas dos parlamentares e membros de sua bancada. Ou seja, os líderes partidários formam a ponte que liga os parlamentares individuais e o Executivo, negociando as demandas de ambos. Portanto, não é racional os parlamentares agirem individualmente no Congresso, como também não é racional o Executivo negociar ou barganhar individualmente o voto de cada parlamentar a cada nova medida que introduz. É necessário que os parlamentares sigam o líder para que este se sinta motivado e comprometido a agir como 
intermediário das demandas dos membros do seu partido junto ao Executivo. É nesse momento que os partidos - frágeis elos entre os representantes e os eleitores - se tornam fortes atores. Fortes sim, mas no espaço congressual e governamental.

Dada essa forma tão peculiar de funcionamento do sistema político brasileiro, acreditamos que existe um falso dilema entre as duas correntes acima referidas. Em linhas gerais, pode-se afirmar que ambas as explicações estão certas e erradas ao mesmo tempo, pois, ao levarem em conta apenas uma das arenas políticas (eleitoral ou legislativa), não percebem a complementaridade existente entre elas. Cada uma dessas abordagens seria, por assim dizer, uma das faces de uma mesma moeda. Ou seja, os argumentos que fundamentam o modelo do "voto pessoal" e aqueles que embasam o modelo do "voto partidário" nem poderiam ser integralmente transpostos para o caso brasileiro, nem poderiam ser totalmente descartados.

O artigo está organizado da seguinte forma. A próxima seção discute, resumidamente, os instrumentos institucionais por meio dos quais o Executivo faz prevalecer as suas preferências no Congresso, com especial ênfase no processo de execução orçamentária. Em seguida, propomos um modelo econométrico multivariado para testar os determinantes do comportamento de voto dos parlamentares no plenário da Câmara dos Deputados. A quarta seção analisa os resultados dos testes em relação a cada uma das hipóteses propostas no modelo. Como decorrência direta destes testes, a quinta seção investiga como funcionaria a conexão eleitoral no Brasil utilizando-se de um modelo econométrico que mensura os determinantes do sucesso eleitoral dos deputados federais que tentaram a reeleição no pleito de 1998. Por fim, a última seção sintetiza os principais achados dos testes e sugere caminhos institucionais para o entendimento da coexistência de partidos fracos e fortes no Brasil.

\section{DOMINÂNCIA DO EXECUTIVO NA ARENA LEGISLATIVA}

De uma forma bastante esquemática, pode-se dizer que o Executivo faz uso de três mecanismos institucionais para fazer valer suas preferências na arena legislativa e, ao mesmo tempo, incentivar o comportamento partidário: primeiro, os poderes constitucionais do presidente de legislar; segundo, a centralização do processo decisório pelos líderes dos partidos da coalizão majoritária no Congresso; e tercei- 
ro, a centralização da distribuição de recursos políticos e financeiros pelo Executivo. Este artigo focalizará a atenção, essencialmente, neste último mecanismo, uma vez que os dois primeiros já foram largamente explorados por Figueiredo e Limongi (1999), Pereira e Mueller (2000; 2002) e Pessanha (2002).

O poder institucional de legislar do Executivo, por um lado, e o sistema centralizado de tomada de decisão dentro do Congresso, por outro, impõem pautas restritivas e limitam o papel dos parlamentares dentro do próprio Congresso. Com todos esses mecanismos institucionais, não é inoportuno inferir que o Executivo tem dominado em larga escala o processo legislativo no Brasil. À primeira vista, parece que os poderes que o Executivo concentra fazem do ato de governar uma tarefa relativamente fácil, ou mesmo que o papel dos parlamentares no Congresso seja extremamente limitado. Esta conclusão, entretanto, pode ser precipitada e enganosa. Embora os poderes constitucionais do presidente sejam muito abrangentes, isso não significa que o Executivo seja forte em todos os aspectos, ou que ele possa realizar todas as suas preferências sem custos. Mesmo possuindo esse grande leque de dispositivos institucionais delegados pelo próprio Legislativo, o Executivo precisa do voto e do apoio do Congresso para aprovar a legislação ordinária e complementar e, principalmente, as reformas constitucionais em todas as etapas e procedimentos institucionais dentro do Congresso, incluindo a apreciação dos projetos pelas comissões e pelo plenário.

Surpreendentemente, o voto partidário tem sido a estratégia preponderante dos parlamentares brasileiros (Figueiredo e Limongi, 1999), e não o voto pessoal, como seria esperado em vista da vigência de um sistema eleitoral descentralizado e de um sistema partidário fragmentado. Defende-se aqui, portanto, a hipótese de que os legisladores brasileiros têm votado consistentemente seguindo a indicação dos seus líderes partidários não só devido aos poderes legislativo e de controlar a agenda do Congresso assegurados ao presidente, mas também por perceberem que esse comportamento pode proporcionar acesso a benefícios controlados pelo Executivo, benefícios esses que têm um forte impacto nas estratégias de sobrevivência política dos parlamentares na esfera eleitoral. Em outras palavras, o voto partidário é a forma encontrada pelos parlamentares de sobreviver politicamente em um ambiente no qual o Executivo desfruta de uma situação institucional privilegiada nas suas negociações com o Legislativo. 
As preferências dos legisladores sofrem, portanto, uma série de influências dentro do escopo aqui descrito: poderes de legislar do Executivo; intermediação e distribuição de benefícios a cargo dos líderes partidários; fragmentação partidária, acompanhada de extrema ligação pessoal entre representante e eleitor na arena eleitoral, porém com a recomposição do poder partidário da arena congressual via distribuição de benefícios controlados pelo Executivo e intermediados pelos líderes da coalizão majoritária. Portanto, para explicar esse complexo e peculiar sistema político é de fundamental importância analisar o processo de distribuição de recursos políticos e financeiros pelo Executivo e suas conseqüências.

Um dos componentes decisivos, embora não o único², do domínio exercido pelo Executivo sobre o comportamento dos parlamentares no Congresso é o processo de execução das emendas individuais dos deputados à Lei Orçamentária Anual - LOA aprovada pelo Congresso e sancionada pelo presidente da República ${ }^{3}$. Embora os deputados tenham o direito constitucional de formular e aprovar emendas ao Projeto de Lei Orçamentária previamente elaborado pelo Executivo, é este último, por meio do Ministério do Planejamento, Orçamento e Gestão, quem de fato executa esse orçamento. Na sua grande maioria, os parlamentares fazem uso dessa prerrogativa apresentando emendas individuais com políticas cujo objetivo é beneficiar os municípios onde obtiveram maior número de votos na eleição anterior, ou seja, suas bases eleitorais (pork barrel politics), como forma de maximizar suas futuras chances eleitorais.

Além do mais, o Executivo brasileiro tem sistematicamente se valido da não-sincronia entre arrecadação efetiva e dispêndios previstos na LOA para contingenciar a execução orçamentária em relação à disponibilidade de recursos, ou para solicitar créditos adicionais. Isto significa uma situação por demais privilegiada para o Executivo nas suas negociações com o Legislativo, uma vez que esses dispositivos institucionais lhe garantem alto grau de discricionariedade e flexibilidade na execução do orçamento.

Existem fortes evidências, que serão demonstradas a seguir, de que o Executivo tem se utilizado do processo de execução das emendas na LOA para recompensar ou punir os parlamentares de acordo com suas performances. Em outras palavras, é esperado que os parlamentares que consistentemente votam de forma favorável às preferências 
do Executivo tenham maiores probabilidades de ver executadas as suas emendas. Por outro lado, os parlamentares que consistentemente se comportam de forma contrária aos interesses do Executivo têm uma probabilidade menor de ver as suas emendas executadas.

\section{TESTANDO O MODELO DE COMPORTAMENTO LEGISLATIVO}

Com o objetivo de testar o comportamento legislativo de cooperar ou não com o presidente, bem como de estimar se realmente o Executivo tem se utilizado da execução das emendas dos parlamentares para garantir apoio às suas preferências, foi realizada uma série de regressões logísticas multivariadas tendo como variável dependente o voto de cada parlamentar em 327 votações nominais (166 votações que envolveram propostas de emenda constitucional - PECs e 161 "Outras" Votações) no plenário da Câmara do Deputados, de 1995 a 1998, tendo por base a posição do Executivo em cada votação. Antes, porém, de analisar os resultados desses testes, é necessário esclarecer algumas pressuposições e os procedimentos aqui utilizados.

De acordo com Luiz Carlos Santos,

“[...] a maior dificuldade que o governo vem enfrentando com o Congresso não é convencer os parlamentares a votarem favoravelmente ao Executivo, mas, sim, alcançar o quórum necessário para aprovar a agenda do Executivo, especialmente nas PECs, quando o governo necessita de uma maioria qualificada de $3 / 5$ dos votos" ${ }^{\prime 4}$.

O que está implícito nesta passagem é a pressuposição de que os parlamentares vêm se comportando estrategicamente em relação às preferências do Executivo, não necessariamente votando contra (o que poderia ser muito custoso para o parlamentar), mas simplesmente não aparecendo no plenário ou mesmo se abstendo em uma determinada votação. Dessa forma, é importante que se considere a posição do governo em cada votação para que o comportamento estratégico do parlamentar seja levado em conta. Em outras palavras, quando a posição do governo é "sim", há apenas um comportamento favorável ao presidente, que é "sim", e três comportamentos contrários à posição do presidente: "não", "ausência" e "abstenção". Entretanto, quando a posição do presidente é "não", ocorre exatamente o oposto; ou seja, para votar a favor do presidente, o parlamentar tem três opções: "não", "abstenção" e "ausência", e, portanto, apenas um com- 
Quadro 2

Opções de Comportamento de Voto em Relação à Posição do Governo

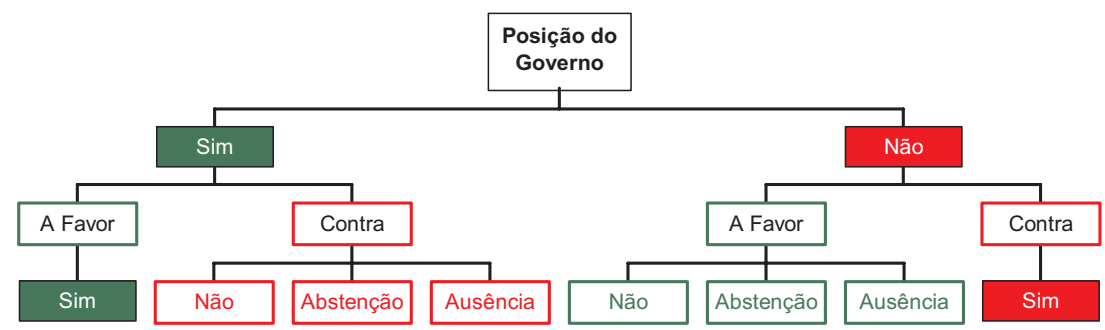

portamento contra, "sim" (ver Quadro 2). Nesta situação, a responsabilidade de conseguir o quórum é da oposição. Esta premissa tem conseqüências importantes para o modelo, especialmente para a variável dependente, pois em vez de quatro opções de voto, a decisão do parlamentar foi reduzida a duas opções: cooperar ou não cooperar com a posição do presidente ${ }^{5}$.

Presume-se também que os legisladores são maximizadores de utilidade. Em outras palavras, suas escolhas de cooperar ou não com o presidente são determinadas pelos possíveis custos e benefícios advindos desse comportamento em termos de: recursos políticos junto ao seu partido por ter seguido a orientação do seu líder; benefícios políticos e financeiros transferidos pelo Executivo como conseqüência do apoio dado ao presidente; e retornos eleitorais provenientes de sua base política por corresponder às suas expectativas. Também se presume que não há hierarquia entre essas opções. De fato, as escolhas dependerão dos cálculos de cada parlamentar em cada votação e contextos diferenciados. Por exemplo, se o deputado sistematicamente seguir a indicação do líder partidário, isto naturalmente pode lhe trazer alguns benefícios políticos importantes, tais como sua indicação para uma posição de destaque em uma comissão, maior empenho de seu líder nas negociações de suas demandas junto ao Executivo, maior acesso a setores do Executivo, ou mesmo ser nomeado ministro ou ter o poder de indicar alguém de sua confiança para um determinado ministério e assim por diante, e/ou benefícios financeiros, tais como conseguir um emprego público para seu(a) sobrinho(a), obter uma dotação orçamentária especial que gere benefícios diretos para seu eleitorado, conseguir uma permissão pública (concessão) de um canal de rádio ou TV e assim por diante. 
Além de separar as votações em dois grandes blocos (PECs e "Outras" Votações), estas também foram agrupadas pelo seu nível de controvérsia / concordância. Assim, foram formados grupos de votações em torno de 50\%, 60\%, 70-74\%, 75-79\%, 80\% e 90\% de concordância. Esta classificação tornou possível estimar o impacto das variáveis explicativas tanto nas votações consensuais, em que $80 \%$ a $90 \%$ dos parlamentares votaram da mesma forma, como nas votações polêmicas, em que $50 \%$ a $60 \%$ dos parlamentares votaram de uma forma e uma outra parcela considerável de deputados votou de modo diferente.

\section{As seguintes variáveis explicativas fizeram parte do modelo:}

(1) a porcentagem média do valor de fato executado, durante os anos de 1995 a 1998, de todas as emendas individuais de cada parlamentar às respectivas leis orçamentárias (budget). Como foi dito anteriormente, é esperada uma correlação positiva entre a porcentagem de execução orçamentária e votos favoráveis ao Executivo;

(2) o total em reais do que foi de fato executado das emendas individuais de cada parlamentar orientadas para o município onde ele obteve maior número de votos nas eleições de 1994 (pork). Em outras palavras, quanto de fato cada parlamentar conseguiu levar, por meio da execução de suas emendas individuais ao orçamento, à sua principal base eleitoral;

(3) o número total de emendas de cada parlamentar designadas para beneficiar o município onde o mesmo obteve maior número de votos nas eleições de 1994, mas não necessariamente executadas ( $n^{0}$ emendas). Esta terceira variável tenta, justamente, capturar o efeito da insatisfação do parlamentar pela possível não execução de suas emendas em seu comportamento de voto, sendo esperada, assim, uma correlação negativa entre essas variáveis;

(4) também foi incluído no modelo o número de vezes que cada legislador mudou de partido político ( $n^{0}$ mudanças) em toda a legislatura. Este número varia de zero, para os deputados que não mudaram de partido, a quatro, para aqueles que mais vezes trocaram de partido político ${ }^{6}$. Essa variável pretende estimar até que ponto o presidente tem mais dificuldades de contar com o apoio dos parlamentares que mais vezes mudaram de partido político, visto que é largamente defendido pelo que as constantes mudanças de partido político no Bra- 
sil fragilizam a capacidade do Executivo de contar com o voto desses parlamentares e, como conseqüência, de aprovar a sua agenda. Dessa forma, é esperado que o coeficiente dessa variável seja negativo;

(5) além de considerar o número de mudanças de partido, o modelo também levou em consideração a direção da mudança, tomando por base os partidos que fazem parte da coalizão do atual governo. Assim, durante o período estudado, 48 parlamentares decidiram migrar para os partidos da coalizão de governo (entrarcoal), enquanto quinze deputados escolheram o caminho inverso, migrando para os partidos de oposição (saircoal). Assim, é esperado que os parlamentares do primeiro grupo apresentem uma maior probabilidade de votar favoravelmente ao governo, e os do segundo grupo, uma maior probabilidade de votar contra o governo;

(6) foram incluídas no modelo algumas variáveis que objetivam estimar o efeito da participação dos parlamentares nos órgãos decisórios e comissões da Câmara nos seus padrões de voto no plenário da Casa, tomando por base as posições que os mesmos ocupam na hierarquia decisória da Mesa Diretora da Câmara, Comissões Permanentes e Comissões Especiais. Assim, a variável Mesa Diretora é uma variável dummy que indica se o parlamentar ocupou alguma das suas posições durante o período de 1995 a 1998. De acordo com o regimento interno da Câmara, as posições na Mesa Diretora são preenchidas seguindo-se o critério de representatividade proporcional dos partidos políticos dentro da Casa. Como a coalizão do atual governo detém a maioria das cadeiras, é esperado que os parlamentares que ocupam estas posições sejam bastante fiéis aos interesses do Executivo, já que são eles que decidirão quais as questões a serem apreciadas e quando elas serão ou não votadas. Conseqüentemente, eles apresentam alta probabilidade de votar de acordo com as preferências do presidente. Raciocínio semelhante é seguido no que diz respeito aos parlamentares que ocupam os principais cargos hierárquicos nas comissões permanentes e especiais (presidente, vice-presidente, relator). Ou seja, é esperado que os legisladores que ocupam posições de liderança em comissões permanentes e especiais apresentem maior probabilidade de votar favoravelmente às preferências do presidente;

(7) como variável de controle foi incluída a distribuição ideológica dos parlamentares, tomando por base as suas filiações partidárias em 1994. Assim, temos três variáveis dummy que representam, respecti- 
vamente, os parlamentares pertencentes a partidos localizados à esquerda, no centro e à direita do espectro ideológico (segundo a classificação de Figueiredo e Limongi, 1999:78)7 ${ }^{7}$. É esperada uma correlação positiva entre parlamentares pertencentes aos partidos de centro e de direita, que dão sustentação política ao atual presidente no Congresso, e comportamento de voto favorável aos interesses do Executivo.

\section{ANÁLISE DOS RESULTADOS DOS TESTES ECONOMÉTRICOS}

Os resultados dos testes multivariados (Tabelas 1 e 2) ${ }^{8}$ confirmaram a grande maioria das hipóteses do modelo. Entretanto, pode-se notar que o modelo apresentou maior capacidade explicativa e de predição nas votações que envolveram PECs, pois nestas votações as variáveis explicativas foram, de uma maneira geral, mais robustas em termos de significância estatística e o modelo apresentou capacidade de predição mais elevada (comparar últimas colunas das Tabelas 1 e 2). Uma possível explicação para este resultado é que, como as PECs exigem maioria qualificada de $3 / 5$ para serem aprovadas, são nessas votações que maiores energias são despendidas em termos de mobilização dos parlamentares, partidos e, principalmente, do Executivo.

Será que pertencer aos partidos políticos que fazem parte da coalizão de governo importa para a definição do comportamento de voto dos parlamentares no plenário da Câmara dos Deputados?

De acordo com os testes econométricos, a resposta para esta pergunta é sim. Como pode ser constatado, os parlamentares que pertencem aos partidos que formam a coalizão de governo votam consistentemente de modo favorável ao governo. Este resultado foi robusto tanto nas PECs como nas "Outras" Votações, mas principalmente quando a posição do governo foi "sim", pois a variável coalizão foi estatisticamente significante em todos os seis níveis de controvérsia das PECs e em cinco das "Outras" Votações - ou seja, quando o Executivo realmente precisou da sua base de apoio parlamentar no Congresso, pois são nessas votações que o governo tem a responsabilidade de prover a maioria.

Por outro lado, quando a posição do governo é "não", essa variável perde parcialmente a capacidade explicativa do comportamento de voto dos parlamentares. Nessas votações, os deputados da base do governo têm incentivos para não comparecer ou se abster, comporta- 
Tabela 1

Determinantes do Voto dos Parlamentares no Plenário da Câmara nas PECs Resultantes de Regressões Logísticas para cada Grupo de Votação

\begin{tabular}{|c|c|c|c|c|c|c|c|c|c|c|c|c|c|c|c|c|c|c|c|}
\hline $\begin{array}{l}\frac{\pi}{0} \\
0 \\
0 \\
0 \\
0 \\
0 \\
0 \\
0\end{array}$ & $\begin{array}{l}\overrightarrow{0} \\
0 \\
\text { : } \\
\text { 品 } \\
0\end{array}$ & $\begin{array}{l}0 \\
0 \\
0 \\
\tilde{J} \\
0 \\
0 \\
\text { il }\end{array}$ & & 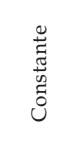 & 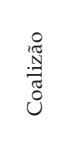 & 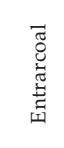 & 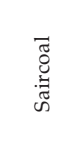 & 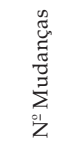 & $\begin{array}{l}\stackrel{\Xi}{\Xi} \\
\text { Ũ }\end{array}$ & 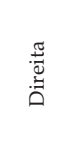 & 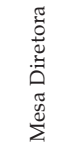 & 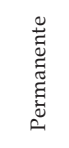 & 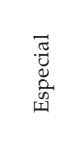 & $\begin{array}{l}\vec{\Xi} \\
\stackrel{\Xi}{\Xi} \\
0\end{array}$ & 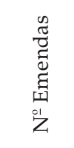 & $\begin{array}{l}\frac{u}{5} \\
2\end{array}$ & 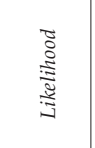 & 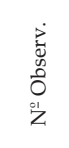 & 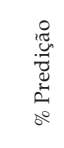 \\
\hline \multirow{4}{*}{$50 \%$} & \multirow[t]{2}{*}{ Sim } & \multirow[t]{2}{*}{2} & Coeff & $-4,061$ & 2,449 & 2,501 & $-0,822$ & 0,808 & 1,170 & 1,406 & 0,822 & 0,121 & 0,706 & 0,224 & $-0,589$ & 0,731 & $-361,34$ & 747 & 75,5 \\
\hline & & & $\mathrm{p}$-value & 0,000 & 0,000 & 0,000 & 0,101 & 0,597 & 0,012 & 0,002 & 0,175 & 0,078 & 0,299 & 0,000 & 0,012 & 0,010 & & & \\
\hline & \multirow[b]{2}{*}{ Não } & \multirow{4}{*}{$\frac{10}{17}$} & Coeff & $-0,476$ & 0,213 & 0,729 & $-0,334$ & 0,492 & 0,734 & 1,089 & 0,904 & $-0,116$ & 0,820 & 0,504 & $-0,366$ & 0,180 & $-2295,45$ & 3752 & 68,6 \\
\hline & & & $\mathrm{p}$-value & 0,000 & 0,229 & 0,000 & 0,126 & 0,441 & 0,000 & 0,000 & 0,970 & 0,658 & 0,770 & 0,029 & 0,000 & 0,098 & & & \\
\hline \multirow{4}{*}{$60 \%$} & \multirow[t]{2}{*}{ Sim } & & Coeff & $-1,311$ & 1,032 & 1,009 & $-0,576$ & 0,139 & 0,530 & 0,591 & 0,532 & 0,393 & $-0,103$ & 0,767 & $-0,159$ & 0,176 & $-3986,17$ & 6381 & 66,69 \\
\hline & & & $p$-value & 0,000 & 0,000 & 0,000 & 0,000 & 0,765 & 0,000 & 0,000 & 0,004 & 0,048 & 0,618 & 0,000 & 0,023 & 0,031 & & & \\
\hline & \multirow[b]{2}{*}{ Não } & \multirow[b]{2}{*}{12} & Coeff & $-0,995$ & 1,026 & 1,281 & $-0,584$ & 0,916 & 0,977 & 0,993 & 0,496 & $-0,149$ & 0,843 & 0,164 & $-0,365$ & 0,289 & $-2090,13$ & 4502 & 81,8 \\
\hline & & & $p$-value & 0,000 & 0,000 & 0,000 & 0,016 & 0,218 & 0,000 & 0,000 & 0,076 & 0,601 & 0,791 & 0,000 & 0,000 & 0,019 & & & \\
\hline \multirow{4}{*}{$70-74 \%$} & \multirow[t]{2}{*}{ Sim } & \multirow[t]{2}{*}{26} & Coeff & $-1,719$ & 1,112 & 1,410 & $-0,765$ & 0,594 & 1,203 & 1,308 & 0,207 & 0,271 & 0,683 & 0,118 & $-0,681$ & 0,257 & $-5080,63$ & 9721 & 76,81 \\
\hline & & & $p$-value & 0,000 & 0,000 & 0,000 & 0,000 & 0,178 & 0,000 & 0,000 & 0,193 & 0,137 & 0,972 & 0,000 & 0,282 & 0,001 & & & \\
\hline & \multirow[b]{2}{*}{ Não } & \multirow[b]{2}{*}{27} & Coeff & $-0,487$ & 0,759 & 1,168 & $-0,787$ & 0,140 & 0,811 & 0,922 & 0.123 & $-0,944$ & 0,148 & 0,134 & $-0,249$ & 0,689 & $-4321,23$ & 10140 & 80,75 \\
\hline & & & $p$-value & 0,000 & 0,000 & 0,000 & 0,000 & 0,012 & 0,000 & 0,000 & 0,000 & 0,641 & 0,522 & 0,000 & 0,000 & 0,000 & & & \\
\hline \multirow{4}{*}{$75-79 \%$} & \multirow[t]{2}{*}{ Sim } & \multirow[t]{2}{*}{22} & Coeff & $-1,589$ & 1,157 & 1,225 & $-0,759$ & 0,151 & 1,333 & 1,374 & 0,307 & 0,275 & $-0,219$ & 0,561 & $-0,129$ & 0,408 & $-4261,25$ & 8221 & 77,77 \\
\hline & & & $\mathrm{p}$-value & 0,000 & 0,000 & 0,000 & 0,000 & 0,003 & 0,000 & 0,000 & 0,083 & 0,989 & 0,916 & 0,001 & 0,059 & 0,000 & & & \\
\hline & \multirow[b]{2}{*}{ Não } & \multirow[b]{2}{*}{7} & Coeff & $-0,235$ & 0,956 & 0,917 & $-1,106$ & 0,226 & 0,590 & 0,940 & 0,729 & 0,142 & 0,169 & 0,122 & $-0,294$ & 0,620 & $-1018,74$ & 2634 & 82,99 \\
\hline & & & $p$-value & 0,137 & 0,000 & 0,001 & 0,001 & 0,066 & 0,030 & 0,001 & 0,121 & 0,741 & 0,732 & 0,001 & 0,030 & 0,001 & & & \\
\hline \multirow{4}{*}{$80 \%$} & \multirow[t]{2}{*}{ Sim } & \multirow[t]{2}{*}{9} & Coeff & $-0,448$ & 0,948 & 0,949 & $-0,860$ & $-0,491$ & 0,604 & 0,653 & 0,852 & $-0,124$ & $-0,201$ & 0,492 & $-0,709$ & 0,331 & $-1803,28$ & 3389 & 75,59 \\
\hline & & & $\mathrm{p}$-value & 0,000 & 0,000 & 0,000 & 0,000 & 0,504 & 0,002 & 0,001 & 0,008 & 0,683 & 0,544 & 0,066 & 0,496 & 0,010 & & & \\
\hline & \multirow[b]{2}{*}{ Não } & \multirow[b]{2}{*}{14} & Coeff & 0,842 & 0,337 & 0,215 & $-0,943$ & 0,170 & 1,032 & 1,396 & 0,803 & $-0,239$ & $-0,157$ & 0,816 & $-0,212$ & 0,434 & $-1466,99$ & 5242 & 90,7 \\
\hline & & & $p$-value & 0,000 & 0,201 & 0,350 & 0,002 & 0,119 & 0,000 & 0,000 & 0,058 & 0,949 & 0,714 & 0,016 & 0,064 & 0,008 & & & \\
\hline & Sim & 16 & Coeff & 1,427 & 0,369 & 0,265 & $-0,112$ & $-0,594$ & $-0,309$ & $-0,245$ & 0,168 & 0,339 & $-0,275$ & $-0,158$ & $-0,118$ & 0,165 & $-2952,94$ & 6015 & 80,59 \\
\hline $90 \%$ & & & $\mathrm{p}$-value & 0,000 & 0,018 & 0,096 & 0,957 & 0,290 & 0,051 & 0,111 & 0,459 & 0,888 & 0,274 & 0,453 & 0,156 & 0,100 & & & \\
\hline & & & Coeff & 1,125 & 0,452 & 0,720 & $-0,811$ & $-0,141$ & 1,088 & 1,344 & 0,998 & 0,817 & 0,183 & 0,792 & $-0,807$ & $-0,286$ & $-377,92$ & 1491 & 92,08 \\
\hline & Não & 4 & $\mathrm{p}$-value & 0,000 & 0,367 & 0,100 & 0,132 & 0,434 & 0,029 & 0,007 & 0,244 & 0,302 & 0,841 & 0,241 & 0,735 & 0,350 & & & \\
\hline Total & Sim & 92 & & & 6 & 6 & 4 & 1 & 6 & 5 & 3 & 2 & 0 & 5 & 3 & 5 & & & \\
\hline Total & Não & 74 & & & 3 & 4 & 4 & 2 & 6 & 6 & 3 & 0 & 0 & 5 & 5 & 5 & & & \\
\hline Total & & 166 & & & 9 & 10 & 8 & 3 & 12 & 11 & 6 & 2 & 0 & 10 & 8 & 10 & & & \\
\hline
\end{tabular}

Fontes: Secretaria da Mesa da Câmara dos Deputados e Secretaria Geral da Presidência da República. 
Tabela 2

Determinantes do Voto dos Parlamentares no Plenário da Câmara nas "Outras" Votações Resultantes de Regressões Logísticas para cada Grupo de Votação

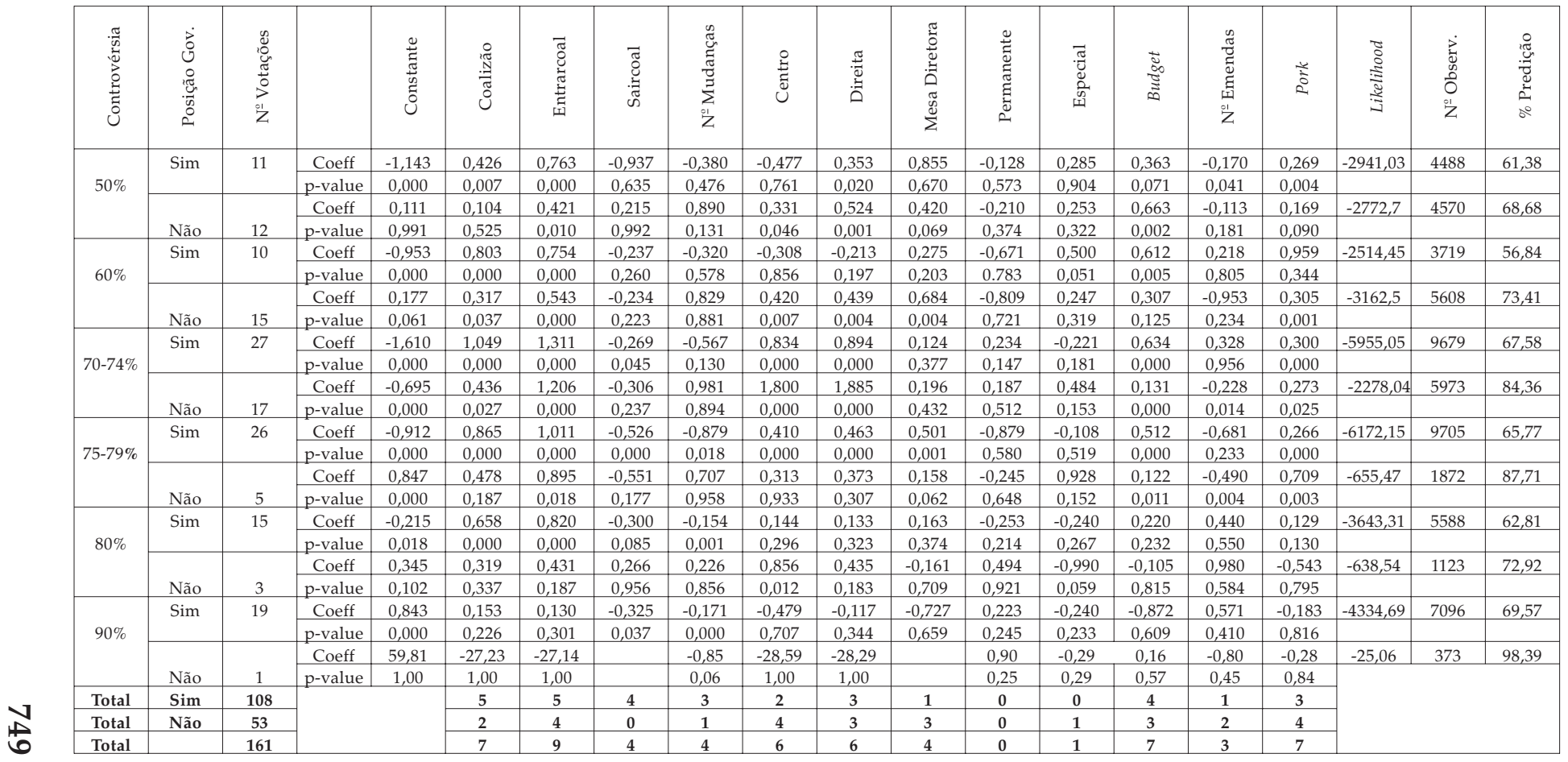


mentos que diretamente beneficiam as preferências do presidente, pois é da responsabilidade da oposição providenciar o número suficiente de votos para aprovar a matéria. Particularmente em relação às PECs, essa situação apenas aconteceu ou nas votações com alto nível de controvérsia (50\%), ou nas votações com alto nível de consenso (80\% e 90\%). No primeiro caso, é possível inferir que a oposição teve sucesso ao atrair alguns votos da base do governo, imprimindo, assim, algumas derrotas ao presidente em votações controversas e com possíveis custos políticos e eleitorais (e.g. reformas da Previdência e administrativa); no segundo caso, entretanto, pode-se facilmente deduzir que não havia incentivos para que os parlamentares da coalizão de governo agissem de forma coesa, visto que até uma parcela considerável da oposição concordava com a posição do governo.

Os parlamentares que mudam de partido político representam um problema para o presidente?

Um resultado que até certo ponto surpreendeu refere-se à variável número de mudanças de partido político, que não apresentou sinais inequívocos de como deve ser interpretada. O primeiro ponto a ser notado é que esta é uma variável pobre em termos da sua capacidade de explicar o comportamento dos deputados, já que ela foi estatisticamente significante apenas três vezes nas PECs e quatro vezes nas "Outras" Votações. Na verdade, o teste oferece interpretações ambíguas. Se, na maioria das PECs, o coeficiente dessa variável foi positivo, contrariando assim a expectativa de que mudar de partido cria problemas para o Executivo aprovar a sua agenda, na maioria das "Outras" Votações o coeficiente foi negativo, confirmando a predição do modelo.

É possível então inferir que mudar de partido não criou problemas para o presidente em votações de reforma constitucional, mas representou uma ameaça nas votações ordinárias. Contudo, é importante que se tenha cautela com esta inferência. Além de ser uma variável pobre em ambos os grupos de votações, quando ela prevê de maneira significativa uma correlação negativa ela o faz nas chamadas votações consensuais. Ou seja, quando o presidente realmente precisou dos votos (durante as votações polêmicas) daqueles parlamentares que mais migraram de partidos ele não se decepcionou. É possível portanto afirmar, embora com precauções, que a mudança de partido político não cria problemas para que o Executivo aprove a sua agen- 
da, ao contrário do que prevê o saber convencional. Este resultado corrobora até certo ponto a proposição de que, quando o parlamentar decide migrar para outro partido, ele o faz, na sua grande maioria, para um partido ideologicamente semelhante ao anterior, não vindo assim a alterar substancialmente o perfil de seu voto (Figueiredo e Limongi, 1999; Melo, 1999).

Resultado mais contundente foi o verificado com relação à direção da migração partidária, ou seja, com respeito às variáveis que estimam o efeito da decisão de entrar ou sair dos partidos da coalizão de governo. Essas variáveis confirmaram integralmente as hipóteses do modelo ao demonstrarem que os 48 deputados que migraram para partidos da coalizão presidencial apresentam maiores probabilidades de votar a favor das preferências do Executivo, enquanto os quinze que decidiram sair da coalizão apresentam maior probabilidade de votar contra o presidente. Dos doze grupos de PECs, a variável entrar coali$z \tilde{a} o$ foi estatisticamente significante e seu coeficiente foi positivo em dez deles, bem como em nove grupos de "Outras" Votações. Ao mesmo tempo, os quinze deputados que decidiram deixar a coalizão de governo apresentaram um padrão sólido de não-cooperação com as preferências presidenciais, especialmente nas PECs. É importante reconhecer que a variável sair coalizão apresentou resultados mais modestos nas "Outras" Votações, pois foi estatisticamente significante apenas quatro vezes. Entretanto, na maioria das vezes seus coeficientes foram negativos, principalmente quando a posição do governo era "sim". Isto significa que, quando o presidente necessitou do apoio desses deputados, ele encontrou grandes dificuldades em contar com esse suporte, como foi previsto no modelo?.

Estes achados sugerem que durante o primeiro mandato de Fernando Henrique Cardoso o governo conquistou uma consistência política ainda maior, atraindo deputados mais fiéis às suas preferências, bem como se livrando dos infiéis. Isto é uma indicação de que a mudança de partido não significa necessariamente mais dificuldades à governabilidade presidencial, como alguns autores advogam (Ames, 2001; Samuels 2000, entre outros). De fato, isto dependerá muito mais da direção da mudança realizada.

Até que ponto os cargos na Mesa Diretora da Câmara e nas Comissões são estratégicos para o Executivo? 
Os testes revelaram que, ao contrário do que o modelo previa, ocupar os principais postos hierárquicos da Câmara dos Deputados tem um efeito pequeno no comportamento de voto dos parlamentares no plenário da Casa. A exceção ficou por conta de ocupar posições na Mesa Diretora da Câmara, que na grande maioria dos casos apresentou coeficiente positivo, embora tenha sido estatisticamente significante em apenas seis grupos de PECs e em quatro grupos de "Outras" Votações. Este resultado ratificou, contudo não de forma tão categórica, a hipótese de que é do interesse do Executivo ter deputados de sua confiança na principal esfera institucional decisória, com poder de definir a agenda do Congresso, bem como de escolher quantas e quais comissões irão analisar os projetos de lei. Em outras palavras, existe maior probabilidade de cooperação com o Executivo por parte dos legisladores que ocupam as posições hierárquicas da Mesa Diretora da Câmara.

Todavia, no que se refere aos postos das comissões permanentes e especiais, estes se revelaram variáveis pobres para explicar o voto dos parlamentares, pois obtiveram uma performance muito fraca nos testes econométricos. A variável comissões permanentes foi estatisticamente significante somente em dois grupos (nas PECs com alto nível de controvérsia, $50 \%$ e $60 \%$, quando a posição do governo era "sim") e a variável comissões especiais em apenas um grupo de votação (nas "Outras" Votações, quando a posição do governo era "não"). Pode-se deduzir, portanto, que o Executivo não está tão preocupado em colocar deputados fiéis nas posições hierárquicas das comissões, já que os legisladores que ocupam aquelas posições não manifestaram seu comportamento de votação de maneira consistente em favor das preferências do presidente.

Esta conclusão, entretanto, parece precipitada, uma vez que em Pereira e Mueller (2000) foram apresentadas claras evidências dos ganhos informacionais obtidos pelo plenário da Câmara e pelo Executivo, quando as comissões são representativas das preferências do plenário. Em outras palavras, o plenário e o Executivo só teriam incentivos para pedir urgência quando as distâncias entre as preferências das comissões e do plenário fossem muito grandes ou quando o custo de espera fosse muito alto. Por outro lado, quando as preferências fossem similares e/ ou o custo de espera fosse baixo, seria do interesse de todos deixar as comissões analisarem os projetos, pois todos se beneficiariam com as informações provenientes das comissões. Os autores 
também demonstraram que há fortes indícios de que o Executivo age estrategicamente substituindo membros infiéis por outros mais confiáveis nas comissões, para garantir resultados consistentes com as suas preferências. Esta suposição foi confirmada pelas respostas de vários deputados que afirmaram que suas "escolhas" de comissões são negociadas ou mesmo impostas pelos líderes de seus partidos e, muitas vezes, contrárias às suas preferências. Ou seja, é plausível inferir que, se as comissões não fossem importantes para o Executivo e para os líderes dos partidos, eles não se preocupariam em interferir na composição das mesmas.

Esses diferentes resultados podem ainda ser associados a instabilidades da própria organização das comissões, pois, como é sabido, as comissões no Brasil apresentam um alto grau de rotatividade na composição de seus membros, não apenas de uma legislatura para outra, mas mesmo de uma sessão para outra. Possivelmente, a forma como essas variáveis foram organizadas no teste econométrico aqui aplicado não permite capturar de maneira apropriada essas características. Diante do aparente resultado contraditório desses testes, é preferível então não assumir posições definitivas e sugerir a necessidade da realização de novas análises, inclusive com testes que comparem diferentes legislaturas.

Até que ponto a execução seletiva de emendas individuais de parlamentares ao orçamento incentiva comportamentos cooperativos com o presidente?

Finalmente, com relação às principais variáveis desse modelo, as que pretendem estimar a influência da distribuição de recursos por parte do Executivo com o objetivo de estimular comportamentos cooperativos, os testes confirmaram de forma consistente as hipóteses do modelo. Ou seja, os parlamentares que conseguiram executar suas emendas individuais, tanto em sua principal base eleitoral (pork) como em todo o estado (budget), apresentam maior probabilidade de votar favoravelmente às preferências do Executivo. Estas duas variáveis foram estatisticamente significantes, na grande maioria das vezes, a $1 \%$ do nível de significância, em dez grupos das PECs e em sete grupos das "Outras" Votações, sempre com o coeficiente positivo, confirmando, assim, as hipóteses do modelo. As únicas vezes em que estas variáveis não apresentaram nível de significância estatística foram nas votações com alto nível de consenso, $90 \%$ nas PECs e $80 \%$ e $90 \%$ nas "Outras" Votações, ou seja, quando o Executivo não precisou de 
uma forte cooperação dos membros de sua base parlamentar, uma vez que já contava com o apoio da oposição. Com resultados tão incisivos quanto estes, a inferência de que o Executivo utiliza a execução das emendas individuais como uma peça importante de negociação com os parlamentares adquire um grande poder explicativo. Além do mais, os deputados têm respondido a estes incentivos de forma bastante favorável aos interesses do presidente.

A variável número de emendas, que significa o número total de emendas de cada parlamentar aprovadas na LOA, mas não executadas pelo presidente, apresentou desempenho semelhante, confirmando a previsão do modelo. Ou seja, quanto maior o número de emendas não executadas, menor o suporte às preferências do Executivo. Entretanto, esta hipótese só foi confirmada de forma consistente nas votações que envolveram PECs, quando foi estatisticamente significante em oito grupos (principalmente nas votações polêmicas), sempre com coeficiente negativo. Nas chamadas "Outras" Votações essa variável teve uma performance mais modesta, pois só apresentou significância estatística em três grupos de votações. Mesmo assim, o coeficiente foi, na maioria das vezes, negativo, o que sugere que apenas a aprovação na lei orçamentária das emendas individuais dos parlamentares não é suficiente para determinar o seu voto favoravelmente ao governo. É necessário que estas sejam executadas de fato. Ou seja, é preciso que o Executivo concretamente entregue os recursos para os projetos individuais dos parlamentares, como indicou o resultado da regressão para as variáveis budget e pork. Do contrário, os parlamentares expressam sua insatisfação com o Executivo votando consistentemente contra a posição do presidente.

Os resultados desses testes nos permitem concluir que é grande o poder exercido diretamente pelo Executivo sobre o comportamento dos parlamentares no Brasil, principalmente daqueles de sua base parlamentar de apoio. Como os testes também fortemente confirmam, os deputados que mais votam com o Executivo são os que pertencem aos partidos de centro e de direita ${ }^{10}$. Não é coincidência, portanto, que esses parlamentares pertencentes aos partidos de centro e de direita sejam justamente os que conseguem ver executadas a maior parte de suas emendas individuais, inclusive aquelas orientadas para beneficiar diretamente o município onde obtiveram maior número de votos. Em outras palavras, é perfeitamente plausível deduzir que o padrão partidário de suporte às iniciativas do Executivo também é for- 
temente mediado pela interferência deste via a distribuição seletiva dos benefícios sob seu controle. Nesse processo, os líderes dos partidos que dão sustentação ao governo no Congresso têm um papel fundamental, pois são eles que defendem as demandas dos seus representados junto ao Executivo.

Por essa razão, não procede a afirmação de Figueiredo e Limongi (2002), imputada ao nosso trabalho (Pereira e Muller, 2002), de que

“Partidos não desempenham nenhum papel nesta explicação. No máximo há uma correspondência entre determinados comportamentos e filiação partidária. O grau de apoio que o presidente obtém de um determinado parlamentar depende tão-somente da execução de suas emendas. O presidente não teria por que discriminar este ou aquele parlamentar com base na sua filiação partidária. O que contaria seria o apoio dado por cada parlamentar à agenda do presidente em cada uma das votações nominais" (Figueiredo e Limongi, 2002:323).

Deixamos claro em várias passagens deste e em outros artigos (Pereira e Mueller, 2002) a importância dos partidos políticos, principalmente no que se refere aos procedimentos institucionais do processo decisório de elaboração e de execução orçamentária. Porém, a mais grave imprecisão da interpretação de Figueiredo e Limongi à nossa análise das relações entre o Executivo e o Legislativo no Brasil se dá quando eles afirmam de forma categórica que

“O modelo explicativo proposto por Pereira e Mueller é uma versão de um argumento mais geral segundo o qual o Legislativo seria capaz de impor a sua vontade ao Executivo. Na medida em que o Executivo depende dos votos dos legisladores para aprovar a sua agenda e não conta com a ameaça de dissolução da legislatura, acaba por ser uma presa dos interesses especiais e localistas dos congressistas. Apoio político só seria obtido quando esses interesses fossem atendidos" (Figueiredo e Limongi, 2002:326).

Por mais inusitado que possa parecer, o nosso principal argumento é justamente o oposto. Ou seja, demonstramos que o Executivo corre poucos riscos de ter a sua proposta alterada contra a sua vontade. Mesmo diante da prerrogativa institucional dos parlamentares de emendar o orçamento e potencialmente desfigurar a proposta original do Executivo, rejeitamos a idéia de que o Executivo é enganado, ou seja, refém do Congresso e propomos uma explicação diferente 
(Pereira e Mueller, 2002:279). Acreditamos que dada a sua estrutura institucional atual, o Executivo tem vários instrumentos para garantir o controle do processo de emendas ao orçamento no Congresso.

“O Executivo não somente detém a prerrogativa exclusiva de determinar o status quo, [...] mas também de estabelecer as diretrizes do processo em combinação com a sua coalizão majoritária que controla a Comissão do Orçamento. E se tudo isso falhar, o governo pode vetar as emendas, total ou parcialmente. Mas existem ainda outras salvaguardas no processo de aprovação do orçamento que impedem que o Congresso modifique a proposta do governo. [...] As regras determinam que o Congresso só pode influir nos recursos da rubrica investimentos, que tem respondido por apenas $1 \%$ a $2 \%$ de todas as despesas orçamentárias. Isso quer dizer que os parlamentares, na realidade, têm muito pouca influência no orçamento total. A maior parte dos itens está não só além do alcance das emendas dos parlamentares, como a parcela que pode sofrer emendas é rigidamente controlada pelo Executivo" (idem:281).

Ao tentarem refutar as evidências por nós apresentadas, Figueiredo e Limongi recorrem à comparação simples das porcentagens de distribuição anual das emendas individuais por partido (2002:324 - Tabela 6), sem se preocupar em controlar essa distribuição por qualquer outra variável que possa influir na decisão do governo no que diz respeito à execução orçamentária, ou mesmo sem utilizar qualquer procedimento estatístico passível de teste, mesmo que fosse um simples teste de médias para determinar se as porcentagens de execução de cada partido seriam estatisticamente diferentes (confirmando, assim, a hipótese alternativa) ou semelhantes (confirmando, assim, a hipótese nula). Talvez por isso eles concluam, equivocadamente, que

“[...] as taxas de execução para o PT em 1997 são similares às do PSDB em 1996, sem que as taxas de apoio de ambos ao presidente mostrem qualquer flutuação significativa. O mesmo deveria se aplicar às taxas de apoio do PDT que, em 1997, teve taxas de execução maiores do que as dos partidos da coalizão governamental no ano anterior, exceção feita ao PFL" (idem:323-324).

Figueiredo e Limongi cometem esse equívoco por compararem a distribuição da execução de emendas por partidos em anos distintos, em vez de fazerem uma comparação dentro do mesmo ano. Se assim o fizessem, poderiam notar que, para todos os anos investigados por es- 
tes autores, nenhum partido de oposição apresentou sua porcentagem de execução maior do que qualquer partido integrante da base aliada do governo. Para dar um exemplo utilizando os mesmos casos usados por Figueiredo e Limongi, o PT sempre apresentou uma porcentagem de execução menor do que o PSDB (1996: PT = 15,7\% e PSDB $=47 \% ; 1997: \mathrm{PT}=44,9 \%$ e $\mathrm{PSDB}=72,5 \% ; 1998: \mathrm{PT}=15 \%$ e $\mathrm{PSDB}=$ $56,1 \% ; 1999: \mathrm{PT}=41,3 \%$ e PSDB $=69,5)$. O mesmo poderia ser constatado em relação ao PDT, que em nenhum ano apresentou porcentagem de execução individual superior a qualquer partido da coalizão de governo naquele mesmo ano.

Mais evidências do uso estratégico da execução das emendas individuais dos parlamentares por parte do Executivo podem ser observadas na Tabela 3, que apresenta a execução das emendas individuais agrupadas por partido político durante o segundo mandato de Fernando Henrique Cardoso (1999 a 2002). Os parlamentares que fizeram parte dos cinco partidos da coalizão do presidente (PFL, PSDB, PMDB, PPB e PTB) receberam, em média, 83,19\% do total dos recursos públicos executados na forma de emendas individuais. Entretanto, esta coalizão ocupava apenas $73,68 \%$ das cadeiras na Câmara dos Deputados. Em outras palavras, os deputados da coalizão de governo executaram mais emendas individuais que o tamanho proporcional de sua bancada na Câmara, enquanto os parlamentares dos partidos de oposição foram sub-recompensados. O exemplo mais marcante deste fato é a diferença do valor total das emendas executadas entre os parlamentares do PTB e do PT, maior partido de oposição. Embora o PT ocupasse quase duas vezes o número de cadeiras $(11,3 \%)$ ocupadas pelo PTB $(6,0 \%)$, seus deputados executaram, em média, menos emendas individuais que os do PTB $-5,8 \%$ versus $7,5 \%$, respectivamente.

Demonstramos, até aqui, que o uso estratégico da liberação das emendas propicia ao Executivo um ganho de votos favoráveis que mais do que compensa a perda decorrente da alteração de sua proposta inicial. É por isso que o governo não somente abre mão de usar os recursos institucionais e as informações de que dispõe para impedir a modificação do seu projeto de orçamento, como incentiva a apresentação de emendas ao sistematicamente superestimar o nível das receitas e despesas esperadas. Não que os congressistas sejam ludibriados por essa estratégia; eles se dispõem a participar desse jogo com o governo porque vêem nele um meio por intermédio do qual a maioria 
Tabela 3

Execução das Emendas Individuais Agrupadas por Partido Político (1999-2002)

(em R\$)

\begin{tabular}{|c|c|c|c|c|c|c|c|}
\hline Partidos & 1999 & 2000 & 2001 & 2002 & $\begin{array}{l}\text { Média dos } \\
\text { Quatro Anos }\end{array}$ & $\begin{array}{c}\% \\
\text { Média }\end{array}$ & $\begin{array}{c}\text { \% Cadeiras } \\
1999\end{array}$ \\
\hline PFL & 3.972 .535 .954 & 6.018 .818 .051 & 7.258 .255 .733 & 6.247 .088 .407 & 5.874 .174 .536 & 27,94 & 20,5 \\
\hline PSDB & 1.811.451.141 & 4.926 .004 .316 & 5.070 .215 .077 & 3.404 .172 .838 & 3.802 .960 .843 & 18,09 & 19,3 \\
\hline PMDB & 2.764.424.397 & 4.998 .939 .073 & 2.935 .365 .427 & 2.426 .383 .266 & 3.281 .278 .041 & 15,61 & 16,2 \\
\hline РPB & 2.879.529.067 & 2.230 .660 .575 & 3.435 .507 .417 & 3.307.422.447 & 2.963 .279 .877 & 14,10 & 11,7 \\
\hline РТВ & 1.335 .750 .904 & 1.119 .496 .892 & 1.422 .358 .214 & 2.391 .002 .136 & 1.567 .152 .037 & 7,45 & 6,0 \\
\hline PT & 987.148 .644 & 1.484 .936 .948 & 1.423 .030 .907 & 940.687 .179 & 1.208 .950 .920 & 5,75 & 11,3 \\
\hline PC do B & 392.974 .045 & 444.168 .786 & 597.124 .393 & 554.191 .316 & 497.114 .635 & 2,36 & 1,4 \\
\hline PDT & 386.497 .529 & 668.714 .368 & 328.156 .800 & 545.747 .815 & 482.279 .128 & 2,29 & 4,9 \\
\hline PL & 25.160 .105 & 238.452 .028 & 305.463 .288 & 1.048 .670 .757 & 404.436 .545 & 1,92 & 2,3 \\
\hline PSB & 580.082 .342 & 245.758 .453 & 306.870 .702 & 141.97.397 & 286.727 .224 & 1,36 & 3,7 \\
\hline PSL & 870.707 & 1.796 .220 & 571.071 .163 & 505.389 .600 & 269.781 .923 & 1,28 & 0,2 \\
\hline PPS & 29.989 .043 & 242.013 .469 & 329.354 .871 & 257.969 .890 & 214.831 .818 & 1,02 & 0,6 \\
\hline PSD & 188.846 .143 & & & & 188.846 .143 & 0,90 & 0,6 \\
\hline Sem Partido & 191.567 .672 & 221.493 .721 & 4.422 .000 & & 139.161 .131 & 0,66 & 1,9 \\
\hline PST & 1.359 .892 & 6.560 .669 & 34.866 .766 & 5.807 .745 & 12.148 .768 & 0,06 & 0,2 \\
\hline PHS & & 1.015 .000 & 5.220 .800 & 60.000 & 2.098 .600 & 0,01 & 0,2 \\
\hline PRTB & & & 1.730 .000 & & 1.730 .000 & 0,01 & \\
\hline PMN & 1.279 .787 & & & & 1.279 .787 & 0,01 & 0,4 \\
\hline PSC & 913.760 & 1.301 .999 & & & 1.107 .880 & 0,01 & \\
\hline PSTB & & 1.039 .708 & & & 1.039 .708 & 0,00 & \\
\hline PV & 740.624 & 1.784 .021 & 1.441 .048 & 100.000 & 1.016 .423 & 0,00 & 0,2 \\
\hline PTN & 549.383 & 1.099 .998 & 548.000 & 100.000 & 574.345 & 0,00 & \\
\hline PSTU & 350.000 & & & & 350.000 & 0,00 & \\
\hline PSDC & & & & 168.000 & 168.000 & 0,00 & \\
\hline Total & 15.552.021.139 & 22.854.054.295 & 24.031 .002 .606 & 21.649.158.793 & 21.021.559.208 & & \\
\hline
\end{tabular}


dos parlamentares possa assegurar sua própria sobrevivência política. Os deputados que fazem parte da coalizão se beneficiam recebendo verbas orçamentárias que, apesar de pequenas em relação à totalidade do orçamento, são suficientes para lhes garantir êxito eleitoral e sobrevivência política (Pereira, 2002; Pereira e Rennó, 2001).

\section{A CONEXÃO ELEITORAL NO BRASIL}

A principal preocupação deste artigo até o momento foi estimar os fatores capazes de exercer influência no comportamento de voto dos parlamentares na Câmara dos Deputados. Foi demonstrado que, em consonância com os poderes do presidente de legislar e de controlar a agenda do Congresso, os parlamentares, principalmente os que pertencem aos partidos da coalizão de governo, cooperam com o presidente, seguindo as orientações de seus líderes partidários como uma estratégia de acesso a benefícios políticos e financeiros que são controlados pelo Executivo, benefícios estes que podem ser usados na arena eleitoral com o objetivo de maximizar suas chances de sobrevivência política. A questão agora é analisar se existe uma conexão eleitoral no Brasil e como ela funciona.

Para tanto, é preciso ser estimado até que ponto é racional, em termos de retornos eleitorais, se comportar de acordo com as preferências do Executivo para ter as demandas atendidas. Em outras palavras, é decisivo saber se esse comportamento dentro do Congresso produz benefícios que possam ser traduzidos em votos na arena eleitoral. Até agora, foi possível afirmar que os legisladores que mais obtiveram sucesso em ver executadas suas emendas individuais ao orçamento também apresentaram um padrão de comportamento de voto no plenário da Câmara consistentemente favorável às preferências do Executivo. Contudo, até que ponto essa estratégia tem provido retornos eleitorais?

Para responder a esta questão, alguns dos determinantes do sucesso da candidatura à reeleição em 1998 foram testados através de uma regressão logística, tendo como variável dependente uma variável dicotômica que diferenciou dois grupos de parlamentares: os que se reelegeram e os que perderam. Em outras palavras, por meio dessa regressão foi testado se a estratégia do deputado de permutar apoio presidencial (comportamento partidário) por pork barrel (execução de 
emendas individuais no orçamento) durante os quatro anos da legislatura de fato trouxe retorno eleitoral.

Dos 615 legisladores, incluindo efetivos e suplentes ${ }^{11}, 446(72,52 \%)$ decidiram ser candidatos à reeleição em 1998, 78 (12,68\%) decidiram não se candidatar a nenhum cargo eletivo, 15 (2,43\%) parlamentares candidataram-se a deputado estadual, $7(1,13 \%)$ candidataram-se a senador e $16(2,60 \%)$ concorreram ao governo dos estados. Dos 446 candidatos à reeleição, $288(64,57 \%)$ foram reeleitos e $158(35,42 \%)$ não obtiveram sucesso. Pode ser coincidência ou mesmo muito cedo para conclusões definitivas, mas o pleito de 1998 foi a primeira eleição legislativa na história da democracia brasileira em que o número de parlamentares reeleitos (288) ultrapassou o número de novos legisladores (225), sugerindo uma espécie de recompensa eleitoral por parte dos eleitores.

A variável explicativa-chave desse teste é a quantidade de pork barrel de fato executada, na forma de emendas individuais dos parlamentares aos orçamentos de 1995 a 1998, orientadas para beneficiar o município onde o parlamentar recebeu maior número de votos na eleição de 1994. O modelo prevê uma correlação positiva entre reeleição e pork barrel. Em outras palavras, quanto maior a quantidade de emendas executadas pelo presidente, maiores as chances de o parlamentar ser reeleito.

Além da execução de emendas individuais no período, o modelo também levou em conta a variável número de emendas, que representa o número de emendas individuais aprovadas no Congresso dirigidas para o município onde o legislador obteve mais votos, mas não necessariamente executadas pelo governo. Em princípio, o efeito esperado dessa variável é ambíguo. Por um lado, o eleitor pode tomar um maior número de emendas como sinal de maior esforço do seu representante. Neste caso, esperar-se-ia um coeficiente positivo. Por outro lado, pode existir uma relação negativa entre o número de emendas apresentadas e não executadas e a probabilidade de reeleição, indicando que não adiantaria apenas que o parlamentar reivindicasse o crédito (claming credit) por ter aprovado uma determinada emenda no orçamento para que obtivesse o reconhecimento da sua base eleitoral e de líderes locais. O que é fundamental é saber se o parlamentar foi eficiente o bastante para, de fato, levar os recursos à sua base ao ver executadas as suas demandas pelo Executivo. 
Além de pork e do número de emendas aprovadas mas não executadas, foi adicionada outra importante variável, gastos 98 , que representa o total de recursos financeiros gastos durante a campanha eleitoral de 1998 oficialmente declarado ao Tribunal Superior Eleitoral. Há uma convicção generalizada de que quanto maior a quantidade de dinheiro gasto, maiores serão as chances de eleição dos legisladores. Ao contrário do que se espera no caso americano, em que os candidatos que mais gastam são os mais vulneráveis e, por isto, com menores chances de reeleição, os gastos de campanha eleitoral no Brasil devem apresentar um efeito positivo direto no sucesso eleitoral, uma vez que a disputa eleitoral em distritos de magnitude superior a um se dá de forma distinta da que ocorre em sistemas majoritários. No caso brasileiro, a competitividade intra e interpartidária aumenta os gastos de campanha (Samuels, 2000). Logo, é defendida a hipótese de que candidatos que investem mais têm maiores retornos eleitorais.

O modelo também pretende avaliar o efeito do comportamento de voto do parlamentar dentro do Congresso na probabilidade de sua reeleição. Assim, a variável votar com o presidente significa uma proporção de quantas vezes cada legislador votou de acordo com as preferências do presidente durante a legislatura 1995-1998. Essa variável funciona como um índice de fidelidade presidencial. Portanto, é esperado que quanto mais o deputado votar com o presidente, maior será a probabilidade de reeleição, já que o presidente desfrutou de uma consistente aprovação popular durante todo o primeiro mandato e é natural que os parlamentares de sua base procurem explorar eleitoralmente esse fato.

Mesmo reconhecendo que esse modelo precisa de uma melhor especificação, como a inclusão de outras variáveis que estimem a performance nacional do parlamentar, para que se possa entender o complexo conjunto de razões que influenciaram o processo de reeleição ${ }^{12}$, é possível dizer que ele demonstra a importância, para um deputado, de conseguir benefícios para a sua base eleitoral. Além disso, a regressão apresentou uma alta capacidade preditiva, por volta de $80 \%$.

O resultado-chave desse teste econométrico é que o coeficiente da variável pork foi positivo e significante (ver Tabela 4), confirmando a hipótese do modelo. Isso significa que, ceteris paribus, quanto maior o montante de emendas individuais do legislador realmente executadas pelo presidente, maiores serão as probabilidades de reeleição do 
parlamentar. O efeito marginal da variável pork foi igual a $26 \%$, ou seja, se um deputado com todas as outras variáveis iguais à média do plenário tivesse todas suas emendas executadas, ele teria $26 \%$ a mais de chance de ser reeleito do que se ele não tivesse nenhuma emenda executada.

Tabela 4

Determinantes da Reeleição em 1998

\begin{tabular}{l|c}
\hline Variável Dep. Reeleição & Coeficientes \\
\hline Constante & 0,820 \\
Pork & $(0,1317)$ \\
& 1,123 \\
No Emendas & $(0,0225)^{* *}$ \\
& $-0,075$ \\
Gastos 98 & $(0,0339)^{* *}$ \\
& $0,208 \times 10^{-5}$ \\
Vota Presidente & $(0,0942)^{*}$ \\
& 0,218 \\
\hline
\end{tabular}

Estimação Logística

Porcentagem de previsão: $79,16 \%$.

Log likelihood: -129,2009.

Número de Observações: 288.

Outro importante resultado do teste foi a determinação da relação entre a variável número de emendas e a probabilidade de reeleição. O seu coeficiente é negativo e estatisticamente significante. Este resultado indica que, quanto maior o número de emendas individuais do legislador aprovadas na LOA, mas não executadas pelo presidente, menor será a probabilidade de este deputado ser reeleito. Ou seja, claiming credit apenas não é suficiente para aumentar as chances de reeleição do parlamentar. O efeito marginal de uma emenda aprovada mas não executada foi reduzir a probabilidade de reeleição em $14 \%$ para um deputado com as características médias.

Estes dois resultados representam forte evidência de que a estratégia dos deputados de seguirem as preferências presidenciais e a indicação dos seus líderes partidários, com a expectativa de obterem acesso a benefícios políticos e financeiros para serem utilizados na arena eleitoral, proporciona consistentes retornos eleitorais. Em uma pala- 
vra, esta é uma das formas pelas quais, de fato, funciona a conexão eleitoral no Brasil.

Confirmando a expectativa, a regressão também indica que gastar mais dinheiro durante a campanha eleitoral conta para a reeleição, dado que esta variável mostra um coeficiente positivo e significan$\mathrm{te}^{13}$. Um aumento dos gastos de campanha de dez mil reais, para um deputado com características iguais à média do plenário, aumenta a probabilidade de reeleição em $5 \%$.

Uma surpresa foi o resultado da variável votar com o presidente, pois embora o seu coeficiente seja positivo, tal variável não foi estatisticamente significante. Isto indica que não há correlação direta entre o comportamento de voto do deputado dentro do Congresso e suas chances de ser reeleito, embora o padrão de voto dos deputados afete indiretamente as chances de reeleição, pois influencia o montante de pork a que este parlamentar terá acesso. Além disso, esse resultado sugere que as bases eleitorais dos parlamentares não constrangem diretamente o comportamento de seus representantes dentro do Congresso. Pode-se inferir que os eleitores estão muito mais preocupados com a capacidade de seus representantes de executarem políticas e benefícios localizados, já que eles recompensam os políticos baseados não no padrão de votação dos seus legisladores ou na posição defendida por seus partidos políticos, mas principalmente baseados nas realizações pessoais do seu representante. Isto nos leva a deduzir que, na arena eleitoral, a grande maioria dos eleitores não se importa com a performance nacional de seus representantes. Em outras palavras, o processo de accountability do sistema político brasileiro é basicamente local.

Portanto, quando os parlamentares estão decidindo como votar no plenário da Câmara dos Deputados, eles estão menos inclinados a levar em consideração a posição de suas bases eleitorais, já que segui-las ou não tem poucas conseqüências para as suas futuras carreiras políticas. O que de fato os orienta estrategicamente é como conseguir os benefícios mediados pelos líderes dos seus partidos e controlados pelo Executivo. Esta é a principal razão pela qual os partidos políticos são tão fortes dentro do Congresso, mas ao mesmo tempo tão fracos na arena eleitoral. Conseqüentemente, também não há nenhuma contradição entre contar com os legisladores votando sistematicamente de acordo com as indicações do líder partidário dentro 
do Congresso e esperar que eles se comportem de maneira particular, buscando benefícios localizados na esfera eleitoral. Muito pelo contrário, estas estratégias se complementam.

\section{CONCLUSÃO}

Este artigo procurou responder à questão: é possível a simultaneidade de partidos políticos fracos na arena eleitoral e partidos fortes dentro do Congresso? A chave para entender este sistema político aparentemente contraditório foi levar em conta a presença de incentivos institucionais paradoxais tanto para o comportamento pessoal como para o comportamento partidário. Como demonstrado, o comportamento dos parlamentares dentro da Câmara dos Deputados tem sido fortemente em conformidade com a indicação dos seus líderes partidários, mesmo diante de todos os incentivos institucionais para um comportamento pessoal e descentralizado proporcionados pelas regras eleitorais e pela fragmentação do multipartidarismo brasileiro.

Além do mais, demonstramos que esse padrão partidário de comportamento parlamentar está estreitamente associado a três elementos institucionais básicos: aos poderes legislativos assegurados constitucionalmente ao presidente; à centralização do processo decisório dentro do Câmara; e principalmente à centralização da distribuição de recursos orçamentários controlados pelo Executivo, recursos estes utilizados pelos parlamentares nas suas respectivas arenas eleitorais para maximizar suas chances e estratégias de sobrevivência política. O Executivo tem usado a distribuição dos recursos para recompensar legisladores fiéis, aprovando suas demandas locais, e ao mesmo tempo punir os parlamentares que não seguem suas preferências, negando-lhes com mais freqüência o acesso a tais recursos.

O grande dilema enfrentado pela maioria dos parlamentares brasileiros é como conciliar duas pressões aparentemente opostas. Em outras palavras, eles têm de satisfazer as reivindicações das suas respectivas circunscrições eleitorais para que tenham condições de sobreviver politicamente, e simultaneamente têm de seguir a indicação dos seus líderes partidários a fim de ter acesso aos benefícios políticos e financeiros controlados pelo Executivo e satisfazer, assim, as demandas locais das suas bases políticas, de modo a obter "retornos eleitorais". É exatamente dessa forma que é completado o ciclo da conexão eleitoral no Brasil (Pereira, 2002). 
Portanto, sustentamos que é perfeitamente possível a coexistência do comportamento partidário dentro do Congresso e do comportamento pessoal na esfera eleitoral, principalmente por meio de políticas locais do tipo pork barrel. Como vimos, o sistema político brasileiro, condensado por um sistema eleitoral que fragiliza os partidos e regras internas que fortalecem os partidos, gera o seu próprio equilíbrio.

(Recebido para publicação em dezembro de 2002)

(Versão definitiva em junho de 2003)

\section{NOTAS}

1. Referimo-nos aqui ao conceito de structure-induced equilibrium utilizado por Shepsle e Weingast (1981). Para estes autores, as regras e procedimentos importam porque elas definem a seqüência dos movimentos dos jogadores em uma dada instituição, gerando, assim, equilíbrio ao delimitar as alternativas de escolhas disponíveis. Ou seja, "structure and procedure combine with preferences to produce outcomes. Equilibrium, if it exists, is affected not only by the distribution and revelation of agent preferences, but also by the way the collectively goes about its business. Indeed, the strategic revelation of agent preferences will depend on this as well" (Shepsle, 1989).

2. Amorim Neto (2002), por exemplo, demonstrou que a alocação de posições ministeriais no Brasil é fortemente associada com a disciplina partidária. É possível também inferir que o Executivo utiliza não apenas a execução orçamentária, mas também outros recursos não-orçamentários como, por exemplo, os controlados pelo BNDES, Banco do Brasil, Caixa Econômica Federal etc., que não são passíveis de controle direto pelo Congresso.

3. Pereira e Mueller (2002) elaboraram um modelo espacial em que explicam o uso estratégico da execução orçamentária por parte do Executivo para fazer valer suas preferências no Congresso Nacional. Os autores sugerem que, embora o custo para manter a coalizão de governo disciplinada no Congresso não seja muito alto, esses recursos são de fundamental importância para a sobrevivência política dos parlamentares.

4. Entrevista realizada no escritório do ministro para Assuntos Políticos, Luiz Carlos Santos, em Brasília, em setembro de 1997.

5. Das 166 votações que envolveram a Proposta de Emenda Constitucional - PEC, em 92 delas a posição do governo foi "sim" e nas 74 restantes foi "não". Já nas 161 votações que não envolveram PECs, em 108 delas o governo defendeu "sim" e nas 53 restantes, "não". 


\section{Carlos Pereira e Bernardo Mueller}

6. Dos 606 parlamentares da amostra analisada (incluindo titulares e suplentes), 159 $(26,23 \%)$ mudaram de partido e 447 (73,76\%) permaneceram no mesmo partido durante a legislatura de 1995 a 1998. Dos 159 deputados que mudaram sua filiação partidária, 125 mudaram uma vez, 26 mudaram duas vezes, sete mudaram três vezes e apenas um parlamentar mudou quatro vezes.

7. Como são variáveis dummies, foi deixada de fora da regressão a variável esquerda (leftout variable), para evitar problemas de multicolinearidade.

8. Por uma questão de espaço, os principais resultados dos testes foram resumidos nestas duas tabelas. Os testes completos, bem como a base de dados, estão disponíveis mediante solicitação. É importante dizer que foi também testada, com diferentes métodos, a presença e severidade de multicolinearidade. Inicialmente foi usada a técnica de "simple correlation among regressors", para medir o grau de severidade de multicolinearidade entre as variáveis. De acordo com este teste, se o coeficiente de correlação é maior que 0,8 ou 0,9 , então a multicolinearidade é um problema. Entretanto, não foi encontrado um único coeficiente maior que 0,9. Em seguida, foi aplicado o teste "variance inflation factor". De acordo com esta técnica, valores maiores que 1,0 implicam que a variável em questão não é ortogonal em relação às demais e, portanto, que a multicolinearidade está presente. Alguns autores usam o valor de 5,0 ou mais como uma referência de multicolinearidade severa. Mais uma vez, nenhuma variável apresentou um valor maior que 5,0.

9. Contudo, é curioso notar que nas votações com alto nível de controvérsia (50\% nas PECs e 50\% e 60\% nas "Outras" Votações), embora os coeficientes desta variável sejam negativos, eles não foram estatisticamente significantes, sugerindo que alguns desses parlamentares que abandonaram a coalizão presidencial continuaram votando com o governo nessas matérias mais polêmicas.

10. A variável centro foi estatisticamente significante em todas as PECs e na metade das "Outras" Votações. Em apenas um grupo de votações, o coeficiente foi negativo, contrariando a expectativa original do modelo. Contudo, este foi um grupo de PECs não-polêmicas (90\% de concordância). A variável direita, por sua vez, foi estatisticamente significante em onze grupos das PECs e em seis das "Outras" Votações. Nas únicas vezes em que os seus coeficientes foram negativos, a variável não foi significante.

11. No Brasil, para cada parlamentar eleito existe um suplente. Alguns desses suplentes exercem seus mandatos por períodos distintos, uma vez que é muito comum que deputados titulares ocupem posições na burocracia federal ou estadual. Como os suplentes tiveram a chance de exercer seu mandato por algum período de tempo, fazendo uso de todas as prerrogativas de um deputado federal, eles foram incluídos na amostra que foi testada. Se não incluíssemos estes deputados suplentes que exerceram mandato, como faz Samuels (2002), estaríamos arbitrariamente excluindo casos válidos e, portanto, cometendo viés de seleção (Geddes, 1990).

12. Para uma análise mais complexa acerca dos determinantes da reeleição para a Câmara dos Deputados em 1998, ver Pereira e Rennó (2001). A conclusão a que estes autores chegam após utilizarem testes multivariados robustos (Heckman Sellection Model), com um cuidado especial de controlar por viés de seleção e por uma série de variáveis que representam dois grupos de estratégias eleitorais distintas (performance local versus nacional), "é que as duas dinâmicas exercem influência nas chan- 
ces de reeleição. Entretanto, diante das opções e recursos disponibilizados durante seus mandatos, a distribuição de benefícios locais proporciona muito mais retornos eleitorais do que as atividades legislativas dentro da Câmara ou as posições de voto assumidas em relação a uma determinada política. Na realidade, os interesses locais prevalecem na arena eleitoral porque as demandas locais parecem ter impacto mais forte no sucesso eleitoral" (idem:352-353). Dito de outra forma, a atividade nacional do parlamentar (i.e. ocupar posições hierárquicas nas comissões ou nos partidos políticos) é principalmente direcionada para as ações que o habilitam a ter mais acesso a recursos que possam ser utilizados na esfera local com o objetivo de sua reeleição. Com esta afirmação não estamos querendo dizer, como sugerem Figueiredo e Limongi (2002:305), que as "taxas de reeleição seriam uma função direta da execução das emendas individuais ao orçamento". Este processo é muito mais complexo e interconectado.

13. Contudo, este resultado deve ser interpretado com cuidado, pois, como foi demonstrado por Pereira e Rennó (2001), o grau de dispersão em relação à média de gasto é enorme tanto em relação aos parlamentares que foram reeleitos como em relação aos que não foram. Isto significa que muitos parlamentares que gastaram muito não foram reeleitos e alguns que gastaram bem menos do que a média o foram. Outro problema é a quantidade de missing values da amostra fornecida pelo Tribunal Superior Eleitoral, uma vez que a grande maioria dos parlamentares que declaram os seus gastos de campanha (98\%) é justamente os que foram reeleitos apenas $82 \%$ dos que perderam informaram os seus gastos ao TSE.

\section{REFERÊNCIAS BIBLIOGRÁFICAS}

AMES, Barry. (1995a), “Electoral Rules, Constituency Pressures, and Pork Barrel: Bases of Voting in the Brazilian Congress". The Journal of Politics, vol. 57, n-2, pp. 324-343. . (1995b), "Electoral Strategy under Open-List Proportional Representation". American Journal of Political Science, vol. 39, no 2, pp. 406-433.

. (2001), The Deadlock of Democracy in Brazil. Ann Arbor, University of Michigan Press.

AMORIM NETO, Octavio. (2002), "Presidential Cabinets, Electoral Cycles, and Coalition Discipline in Brazil", in S. Morgenstern e B. Nacif (eds.), Legislative Politics in Latin America. Cambridge, Cambridge University Press, pp. 48-78.

e SANTOS, F. (2001), “A Conexão Presidencial: Facções Pró e Antigoverno e Disciplina Partidária no Brasil”. Dados, vol. 44, noㅡ 2, pp. 291-321.

BOWLER, S. (2000), "Parties in Legislatures: Two Competing Explanations", in R. Dalton e M. Wattenberg (eds.), Parties without Partisans: Political Change in Advanced Industrial Democracies. Oxford, Oxford University Press, pp. 157-179. 


\section{Carlos Pereira e Bernardo Mueller}

CAIN, B., FEREJOHN, J. e FIORINA, M. (1987), The Personal Vote: Constituency Service and Electoral Independence. Cambridge, Harvard University Press.

COX, G. (1987), The Efficient Secret: The Cabinet and the Development of Political Parties in Victorian England. Cambridge, Cambridge University Press. e MCCUBBINS, M. (1993), Legislative Leviathan: Party Government in the House. Berkeley, University of California Press.

DOWNS, A. (1957), An Economic Theory of Democracy. New York, Wiley.

FIGUEIREDO, A. e LIMONGI, F. (1995), “Mudança Constitucional, Desempenho Legislativo e Consolidação Institucional". Revista Brasileira de Ciências Sociais, ano 10, no 29, pp. 175-200.

. (1997), Presidential Power and Party Behavior in the Legislature. Trabalho apresentado em encontro da Latin American Studies Association - LASA, Guadalajara, México.

. (1999), Executivo e Legislativo na Nova Ordem Constitucional. São Paulo, Fundação Getulio Vargas Editora.

. (2000a), Executivo e Legislativo na Formulação e Execução do Orçamento Federal. Trabalho apresentado em encontro anual da Associação Brasileira de Ciência Política - ABCP, São Paulo.

. (2000b), “Presidential Power, Legislative Organization, and Party Behavior in Brazil". Comparative Politics, vol. 32, no 2, pp. 151-170.

. (2002), “Incentivos Eleitorais, Partidos e Política Orçamentária”. Dados, vol. 45, no 2, pp. 303-344.

GEDDES, B. (1990), "How the Cases You Choose Affect the Answers You Get: Selection Bias in Comparative Politics". Political Analysis, n으 2, pp. 131-152.

HAGGARD, S. (1995), The Reform of the State in Latin America. Trabalho apresentado na Annual World Bank Conference on Development in Latin America and Caribbean. Rio de Janeiro.

_ e KAUFMAN, R. (1992), The Politics of Economic Adjustment: International Shocks, Distributive Conflicts and the State. Princeton, Princeton University Press.

LAMOUNIER, B. (1989), Partidos e Utopias: O Brasil no Limiar dos Anos 80. São Paulo, Loyola.

MAINWARING, S. (1999), Rethinking Party Systems in the Third Wave of Democratization: The Case of Brazil. Stanford, Stanford University Press.

e SHUGART, M. (1997), Presidentialism and Democracy in Latin America. Cambridge, Cambridge University Press.

MAINWARING, S. e SCULLY, T. R. (1995), Building Democratic Institutions: Party Systems in Latin America. California, Stanford University Press.

MAYHEW, D. (1974), Congress: The Electoral Connection. New Haven, Yale University Press.

MELO, C. R. (1999), Retirando as Cadeiras do Lugar: Migração Partidária na Câmara dos Deputados. Tese de Doutorado, Universidade Federal de Minas Gerais. 
MENEGUELLO, R. (1998), Partidos e Governo no Brasil Contemporâneo (1985-1997). São Paulo, Paz e Terra.

PEREIRA, C. (2002), “Institutional Conditions for Presidential Success in the Legislative Arena? The Electoral Connection in Brazilian Politics". Working Paper, Centre for Brazilian Studies, University of Oxford, no CBS-27-02 (http://www.brazil.ox.ac.uk/workingpapers/Pereira27.pdf).

_ e MUELLER, B. (2000), “Uma Teoria da Preponderância do Poder Executivo. OSistema de Comissões no Legislativo Brasileiro". Revista Brasileira de Ciências Sociais, vol. 15 , n- 43 , pp. $45-67$.

. (2002), “Comportamento Estratégico em Presidencialismo de Coalizão: As Relações entre Executivo e Legislativo na Elaboração do Orçamento Brasileiro". Dados, vol. 45, n을, pp. 265-301.

PEREIRA, C. e RENNÓ, L. (2001), “O que É que o Reeleito Tem? Dinâmicas Político-Institucionais Locais e Nacionais nas Eleições de 1998 para a Câmara dos Deputados". Dados, vol. 44, no 2, pp. 323-362.

PESSANHA, C. (2002), "O Poder Executivo e o Processo Legislativo nas Constituições Brasileiras: Teoria e Prática", in L. Werneck Vianna (org.), A Democracia e os Três Poderes no Brasil. Belo Horizonte/Rio de Janeiro, Editora UFMG/IUPERJ/FAPERJ.

SAMUELS, D. (2000), "Ambition and Competition: Explaining Legislative Turnover in Brazil". Legislative Studies Quarterly, vol. XXV, n-3, pp. 481-498.

. (2002), "Pork Barrelling Is Not Credit Claiming or Advertising: Camping Finance and the Sources of Personal Vote in Brazil". Journal of Politics, vol. 64, no 3, pp. 845-863.

SHEPSLE, K. (1989), "Studying Institutions: Some Lessons from Rational Choice Approach". Journal of Theoretical Politics, vol. 1, no 2, pp. 131-147. e WEINGAST, B. (1981), “Structure-Induced Equilibrium and Legislative Choice". Public Choice, no 37, pp. 503-519. 


\section{GLOSSÁRIO}

PC do B - Partido Comunista do Brasil

PDT - Partido Democrático Trabalhista

PFL - Partido da Frente Liberal

PHS - Partido Humanista da Solidariedade

PL - Partido Liberal

PMDB - Partido do Movimento Democrático Brasileiro

PMN - Partido da Mobilização Nacional

PPB - Partido Popular Brasileiro

PPS - Partido Popular Socialista

PRTB - Partido Renovador Trabalhista Brasileiro

PSB - Partido Socialista Brasileiro

PSC - Partido Social Cristão

PSD - Partido Social Democrático

PSDB - Partido da Social Democracia Brasileira

PSDC - Partido Social Democrata Cristão

PSL - Partido do Solidarismo Libertador

PST - Partido Social Trabalhista

PSTB - Partido Social Trabalhista Brasileiro

PSTU - Partido Socialista dos Trabalhadores Unificado

PT - Partido dos Trabalhadores

PTB - Partido Trabalhista Brasileiro

PTN - Partido Trabalhista Nacional

PV - Partido Verde 


\section{ABSTRACT \\ Weak Parties in the Electoral Arena, Strong Parties in the Legislative Arena: The Electoral Connection in Brazil}

This article analyzes the determinants of voting positions in the Brazilian House of Representatives (Chamber of Deputies) in relation to the preferences of the Executive Branch, focusing on the reasons leading Deputies to cooperate with or resist the President's interests on votes. The article examines the role played by political parties in the Deputies' behavior both inside and outside Congress, as well as the main instruments used by the Executive to encourage cooperative legislative behavior, applying a multivariate econometric model to estimate the determinants of Deputies' votes. The authors conclude that Deputies, especially those belonging to parties in the government coalition, cooperate with the President, following the orientation provided by their party leaders, as a strategy to access political and financial benefits controlled by the Executive, which in turn can be used in the electoral arena in order to maximize their odds of political survival, and that these same Deputies are the ones with the greatest odds of being reelected.

Key words: political parties; Legislative Branch; voting determinants; Executive Branch

\section{RÉSUMÉ}

Partis Faibles sur la Scène Électorale et Partis Forts sur la Scène Législative: Connexion Électorale au Brésil

Dans cet article, on cherche à examiner ce qui détermine le vote à la Chambre des Députés par rapport aux préférences du Pouvoir Exécutif, en montrant surtout les raisons qui mènent les députés à voter dans le sens des intérêts du Président. On y examine - à l'aide de l'application d'un modèle économétrique multivarié qui évalue les déterminants du vote - le rôle joué par les partis politiques sur le comportement des parlementaires à l'intérieur et en dehors du Congrès, ainsi que les principaux outils employés par le Pouvoir Exécutif pour attirer leur coopération. On conclut que les parlementaires, surtout ceux qui se trouvent dans les partis de coalition gouvernementale, coopèrent avec le Président, suivant les directives de leurs chefs politiques, en vue d'obtenir du Pouvoir Exécutif des avantages politiques et financiers qui pourront leur servir dans la lutte électorale, dans l'optique de leur réélection, et que les parlementaires sont ceux qui possèdent les plus fortes chances d'être réélus.

Mots-clé: partis politiques; Pouvoir Législatif; déterminants du vote; Pouvoir Exécutif 